\title{
Minerals of Rare Earth Elements in High-Phosphorus Ooidal Ironstones of the Western Siberia and Turgai Depression
}

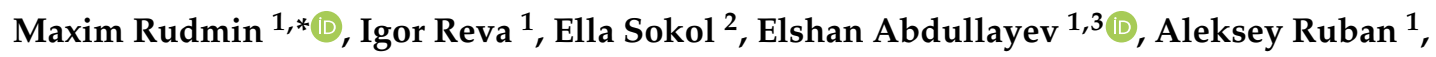 \\ Andrey Kudryavtsev ${ }^{4}$, Oleg Tolkachev ${ }^{5}$ and Aleksey Mazurov ${ }^{1}$ \\ 1 Division for Geology, Tomsk Polytechnic University, 634050 Tomsk, Russia; igor_1993@mail.ru (I.R.); \\ elabdulla3@gmail.com (E.A.); ruban@tpu.ru (A.R.); akm@tpu.ru (A.M.) \\ 2 V.S. Sobolev Institute of Geology and Mineralogy Siberian Branch Russian Academy of Sciences, \\ 630090 Novosibirsk, Russia; sokol@igm.nsc.ru \\ 3 Department of Geoscience, French-Azerbaijani University (UFAZ), Baku AZ1000, Azerbaijan \\ 4 TESCAN Ltd., 195220 Saint-Petersburg, Russia; aka@tescan.ru \\ 5 Division for Materials Science, School of Advanced Manufacturing Technologies, Tomsk Polytechnic \\ University, 634050 Tomsk, Russia; ole.ts@mail.ru \\ * Correspondence: rudminma@tpu.ru; Tel.: +78-3822-60-62-45
}

Received: 28 October 2019; Accepted: 20 December 2019; Published: 21 December 2019

\begin{abstract}
The aim of this research was to study the rare earth (REE) minerals in ooidal ironstone deposits of the West Siberian basin and the Turgai depression. Authigenic minerals (monazite and cerite) were described, and their main mineral form was identified as light rare earth element phosphate (LREE-phosphate) in this study. LREE-phosphate is included in ferruginous ooids, peloids, and oncoids and forms a consistent mineral association with Fe-hydroxides (goethite and its hydrated amorphous derivatives) and Fe-rich layered silicates (Fe-illite-smectite, chamosite, berthierine). The constancy of the mineral association in two deposits of different ages indicates a general mechanism behind the formation of these minerals. LREE-phosphates (authigenic monazite) are characterized by microscopic sizes (up to $24 \mu \mathrm{m}$ ), diverse morphology (mainly spherical or xenomorphic), and occupy spaces between the micro-cortex in ferruginous spheroids. This mineral can be found in other deposits of ooidal ironstone. According to its mineralogical and chemical characteristics, LREE-phosphate mainly belongs to the authigenic (nodular or "gray") monazite. However, the incomplete (not 100\%) correspondence of Kikuchi bands with the reference monazite does not allow its reliable identification. Based on its small size, chemical leaching or bacterial interaction is recommended to extract REE from ooidal ironstone while predicting the associated removal of phosphorus from iron ore due to its dominant phosphate mineral form. Ooidal ironstone should be considered a complex deposit and an unconventional natural type of REE ores as an example of the largest Bakchar and Lisakovsk deposits.
\end{abstract}

Keywords: rare earth elements; ooidal ironstones; phosphates; mineral association; complex deposit

\section{Introduction}

The ooidal ironstone is a chemogenic sedimentary rock that was formed during the Phanerozoic Eon [1-3]. Modern analogues of ooidal ironstones exist in rare cases, such as near the island of Mahengetang in Indonesia [4,5], near the island of Trinidad on the north-east coast of Venezuela [6], and around the island of Panarea in Italy [7]. The Phanerozoic ooidal ironstones have a lateritic, volcanism or hydrothermal origin [8-15]. The ooidal iron ore has long served as the main source of iron for metallurgy until it was replaced by magnetite and hematite ores with endogenous deposits. 
These ores are characterized by a high content of bulk iron and a low content (or complete absence) of detrimental impurities of phosphorus relative to the goethite ore.

Sedimentary ores consist of ooids, peloids, pisoids, etc., the composition of which is represented by a mixture of various minerals. The main minerals are $\mathrm{Fe}^{3+}$-(oxy)hydroxides (goethite $(\alpha-\mathrm{FeO}(\mathrm{OH})$, lepidocrocite, as well as an amorphous hydrated phase, known as hydrogoethite $\left.\left(\mathrm{FeO}(\mathrm{OH}) \cdot x \mathrm{H}_{2} \mathrm{O}\right)\right)$ and $\mathrm{Fe}^{2+}$-layered silicates (chamosite $\left(\left(\mathrm{Fe}^{2+}, \mathrm{Mg}\right)_{5} \mathrm{Al}\left(\mathrm{AlSi}_{3} \mathrm{O}_{10}\right)(\mathrm{OH})\right)$, berthierine $\left.\left(\left(\mathrm{Fe}^{2+}, \mathrm{Fe}^{3+}, \mathrm{Al}, \mathrm{Mg}, \mathrm{Mn}\right)_{2}(\mathrm{Si}, \mathrm{Al})_{2} \mathrm{O}_{5}(\mathrm{OH})_{4}\right)\right)[3,16,17]$. Besides iron, the ooids contain relatively high contents of $\mathrm{Si}, \mathrm{Al}, \mathrm{Mg}, \mathrm{P}, \mathrm{K}, \mathrm{Ti}$, and $\mathrm{V}$, as well as rare earth elements (REEs) [18-20]. Moreover, REEs have positive correlations with $\mathrm{P}$ and/or Fe $[18,20]$. Phosphorus occurs in ooidal ironstones as a mechanical admixture, adsorbed form [14,21-25], or an individual authigenic mineral [8,26-28] formed by diagenesis. Among the phosphorus minerals in ooidal iron ore, francolite $\left(\mathrm{Ca}_{5}\left(\mathrm{PO}_{4}\right.\right.$, $\left.\left.\mathrm{CO}_{3}, \mathrm{OH}\right)_{3} \mathrm{~F}\right)[29,30]$, apatite $\left(\mathrm{Ca}_{5}\left(\mathrm{PO}_{4}\right)_{3}\right)(\mathrm{OH}, \mathrm{F}, \mathrm{Cl})$, fluroapatite $\left(\mathrm{Ca}_{5}\left(\mathrm{PO}_{4}\right)_{3} \mathrm{~F}\right)$, hydroxyapatite $\left(\mathrm{Ca}_{5}\left(\mathrm{PO}_{4}\right)_{3}(\mathrm{OH})\right)$, chlorapatite $\left(\mathrm{Ca}_{5}\left(\mathrm{PO}_{4}\right)_{3} \mathrm{Cl}\right)$, vivianite $\left(\mathrm{Fe}^{2+}{ }_{3}\left(\mathrm{PO}_{4}\right)_{2} \cdot 8 \mathrm{H}_{2} \mathrm{O}\right)$, and its oxidative derivatives, such as metavivianite $\left(\mathrm{Fe}^{2+}{ }_{3-\mathrm{x}} \mathrm{Fe}^{3+}{ }_{\mathrm{x}}\left(\mathrm{PO}_{4}\right)_{2}(\mathrm{OH})_{\times} \cdot(8-\mathrm{x}) \mathrm{H}_{2} \mathrm{O}\right)[13,22,31]$, mitridatite $\left(\mathrm{Ca}_{2} \mathrm{Fe}_{3}{ }^{3+}\left(\mathrm{PO}_{4}\right)_{3} \mathrm{O}_{2} \cdot 3 \mathrm{H}_{2} \mathrm{O}\right)$, bosphorite $\mathrm{Fe}_{3}{ }^{3+}\left(\mathrm{PO}_{4}\right)_{2}(\mathrm{OH})_{3} \cdot 5 \mathrm{H}_{2} \mathrm{O}$ [31,32], strengite $\left(\mathrm{FePO}_{4} \cdot 2 \mathrm{H}_{2} \mathrm{O}\right)$ [33], and recently REE-phosphate [34-36], have been detected. Moreover, various early diagenetic minerals of REEs, such as REE aluminophosphates, like florencite-Ce $\left(\mathrm{CeAl}_{3}\left(\mathrm{PO}_{4}\right)_{2}(\mathrm{OH})_{6}\right)$, gorceixite $\left((\mathrm{Ba}, \mathrm{LREE}) \mathrm{Al}_{3}\left(\mathrm{PO}_{4}\right)\left(\mathrm{PO}_{3} \mathrm{OH}\right)(\mathrm{OH})_{6}\right)$ [37-39], parisite $\left(\mathrm{CaREE}_{2}\left(\mathrm{CO}_{3}\right)_{3} \mathrm{~F}_{2}\right)$ [40,41], and synchysite $\left(\mathrm{CaREE}\left(\mathrm{CO}_{3}\right)_{2} \mathrm{~F}\right)$ [42], are found in sedimentary deposits, whose presence should be confirmed or disproved in sedimentary iron ores.

If we consider the increasing importance of REE for global industry [43], it becomes clear that we must evaluate the new industrial and genetic types of their deposits. In this respect, goethite ooidal iron ore has been studied to search for REE extracting potential [44]. The REE and Fe extraction will make it possible to consider ooidal ironstones as complex deposits to increase the investment attractiveness of sedimentary deposits and their rational development. Thus, the types (varieties) of ooidal ironstones, where a considerable part of the total REE budget is hosted by crystalline compounds/minerals (namely REE phosphates), remains a crucial element of study [35,45]. To assess the eco-friendly and economically efficient ways of iron ores' utilization, it is important to evaluate REE contamination in ironstone deposits. REE can also be extracted in the process of purifying these ores from phosphorus (as a detrimental impurity), taking into account the possibilities of unconventional methods [46]. The goal of this work was to study the REE minerals in high phosphorus ooidal iron ore to understand the resource potential of these deposits, possible technologies for their selective extraction, as well as their origin.

\section{Materials and Methods}

We selected two ooidal ironstone deposits (Figure 1a) from different sedimentological settings for the identification and characterization of the REE-rich minerals/phases.

\subsection{Studied Areas}

\subsubsection{Upper Cretaceous-Lower Paleogene Bakchar Deposit}

The oldest deposit is the Upper Cretaceous-Lower Paleogene Bakchar deposit with gigantic iron resources (about 28 billion tons) [47]; this deposit is located in Western Siberia (near Tomsk city, Russia). The Bakchar deposit is the main deposit of the West Siberian iron ore basin and is a coastal-marine sedimentary sequence with a thickness of up to $80 \mathrm{~m}$ (Figure $1 \mathrm{~b}$ ), containing iron ore layers and lenses $[35,36,47]$. This deposit is located in the southeastern part of western Siberia $\left(52^{\circ} 01^{\prime} 45^{\prime \prime} \mathrm{C}\right.$; $82^{\circ} 07^{\prime} 20^{\prime \prime}$ B, Figure 1a), $200 \mathrm{~km}$ from Tomsk city to the north-west. Iron ore deposits occur at a depth of 157 to $230 \mathrm{~m}$ among Upper Cretaceous and Paleogene rocks [47-53]. The ore-bearing layers of the Bakchar deposit occur in a transgressive complex, where there was a marine-coastal and shallow environment. This deposit is located in the sedimentary cover of the West Siberian Plate and is related 
to the northern end of the domed structure of the Mesozoic, which is called the Bakchar tectonic uplift [47]. A gentle plunge of ore horizons occurs in the northwest and east of the axis of the watershed of the Galka and Bakchar rivers. In the western part of the deposit, the roof of the upper stratigraphic ore level (Bakchar ironstone) lies at a depth of 157 to $160 \mathrm{~m}$ from the surface while in the eastern part, the roof lies at a depth of 170 to $175 \mathrm{~m}$ from the surface.
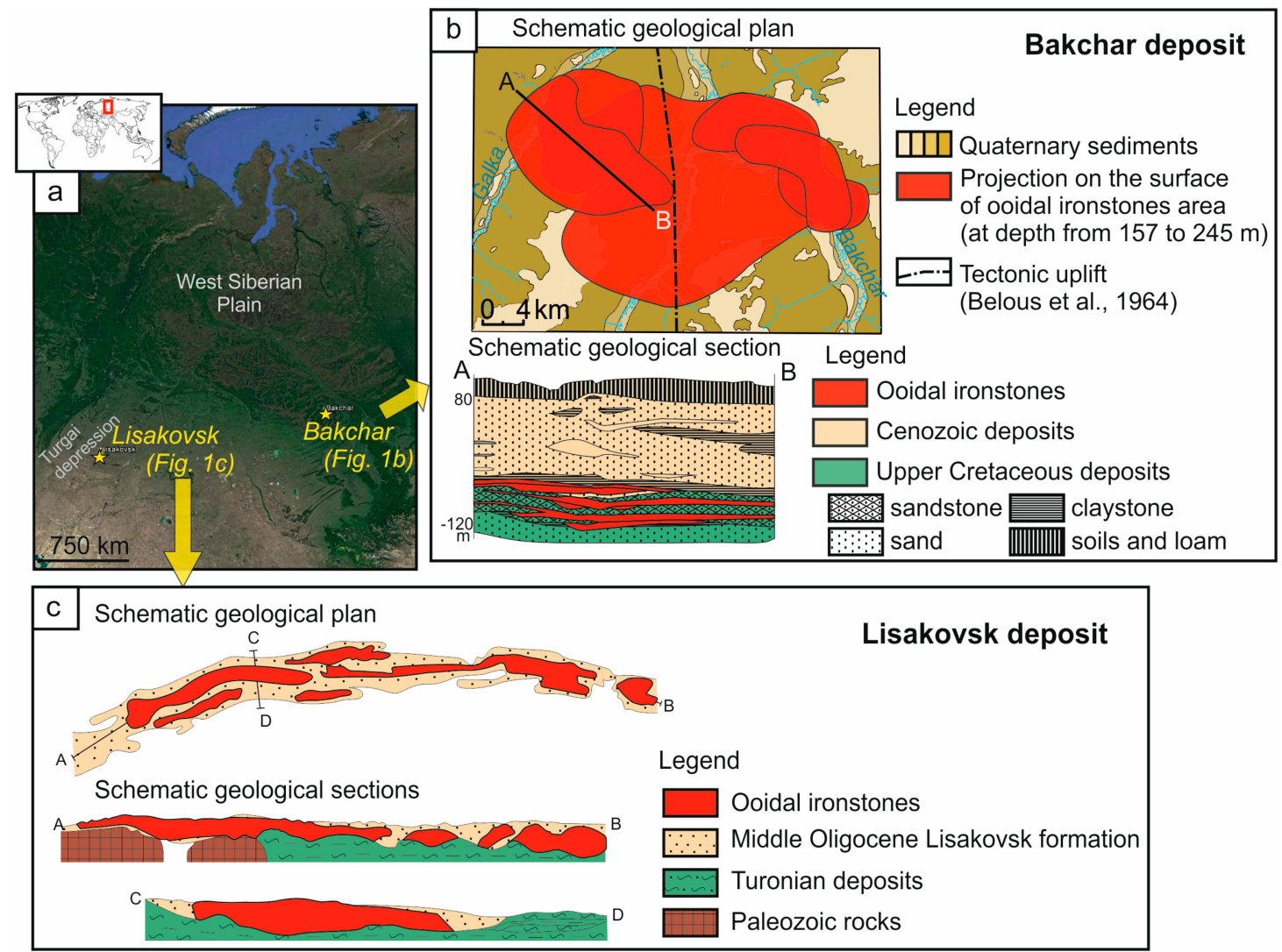

Figure 1. (a) Location of the studied deposits of ooidal ironstone. (b) Schematic geological map and geological section of the Bakchar deposit. (c) Schematic geological map and geological section of the Lisakovsk deposit.

The accumulation of iron ores occurred in a subtropical warm climate in the coastal zone of the Cretaceous-Paleogene West Siberian Sea for about 45 Ma from the Coniacian to the Eocene [47,50,52]. The sedimentation rate is estimated from 0.4 to $1.5 \mathrm{~cm} / 1000$ years [47]. The sea depth and coastline have repeatedly changed, which is reflected in the accumulation of both clay and sandy sedimentary rocks in the Kuznetsovo, Ipatovo, Slavgorod, and Gan'kino Formations (Upper Cretaceous period) [50,54]. Before Maastrichtian times, the West Siberian Sea was connected through the Turgai Strait with the Peritethys Ocean [55-57]. The regression of the sea and gradual shallowing of the basin took place during the Maastrichtian, when the Bakchar deposit was characterized by the accumulation of the sandy layers of the Gan'kino Formation containing Kolpashevo ironstone of goethite ore with chamosite and glauconite. Climatic alternation occurred at the beginning of the Paleogene, after the maximum transgression in the Eocene and the accumulation of claystones of the Lyulinvor Formation, which overlap the Bakchar ironstone of goethite ore with siderite. In tectonic terms, the sedimentation took place in the plunging condition of the West Siberian basin. Vibe et al. [58] indicated that the West Siberian basin experienced varied and prolonged vertical motion from its inception in the Triassic to today. Rapid tectonic subsidence in the Triassic and Early Jurassic was followed by a slowdown in the Late Jurassic-Cretaceous. Slow Paleocene subsidence continued until the Middle Oligocene, when the basin experienced renewed uplift. Tectonic subsidence in Jurassic deposits of the south-eastern West 
Siberian basin reached 2.5 to $3 \mathrm{~km}$, but early Paleogene deposits were associated with uplift [58]. This suggests that early Paleogene sediments in the Bakchar deposit did not undergo deep burial, which is supported by their unlithified nature.

Most part of the ores are concentrated in three stratigraphic levels: As Bakchar, Kolpashevo, and Narym, whose ages are 56 to 62, 72 to 84, and 90 to $96 \mathrm{Ma}$, respectively, based on biostratigraphy and $\mathrm{K}$-Ar dating of glauconite $[47,48,50,52]$. The iron resources of the deposit are estimated at 28 billion tons [47]. The Bakchar ironstone is localized at the bottom of the Lyulinvor Formation (Early Paleogene). The lower part of the Lyulinvor Formation is represented by medium-grained sands and sandstones with a thickness of ooidal iron ore, which are overlapped by gray parallel-layered clays. The Kolpashevo ironstone lies in the Slavgorod (Santonian-Campanian, Upper Cretaceous) and Gan'kino (Maastrichtian, Upper Cretaceous) Formations, which are composed of glauconite sandstones, siltstones, and silty clays. The Narym ironstone is located in the top of the Ipatovo Formation (Coniacian, Upper Cretaceous), which overlays marine clays and fine-grained sandstones of the Kuznetsovo Formation (Cenomanian, Upper Cretaceous).

Iron ores consist of spheroids (ooids, peloids, oncoids, etc. [3]), cemented (Figure 2a) or not. Spheroids mainly consist of goethite and its hydration products (hydrogoethite), as well as layered $\mathrm{Fe}^{2+}$ silicates-chamosite and/or berthierine [35,59]. The cement composition, depending on the redox regime during sedimentation, varies from predominated $\mathrm{Fe}^{3+}$ (oxy)hydroxide or clayey-enriched $\mathrm{Fe}^{3+}$ (oxy)hydroxide to clayey and $\mathrm{Fe}^{2+}$-bearing carbonate ones, and finally to $\mathrm{Fe}^{2+}$-carbonate. On top of the Bakchar ironstone, siderite replaces clay cement and ooids, which reveals its late diagenetic or hydrothermal origin [60].
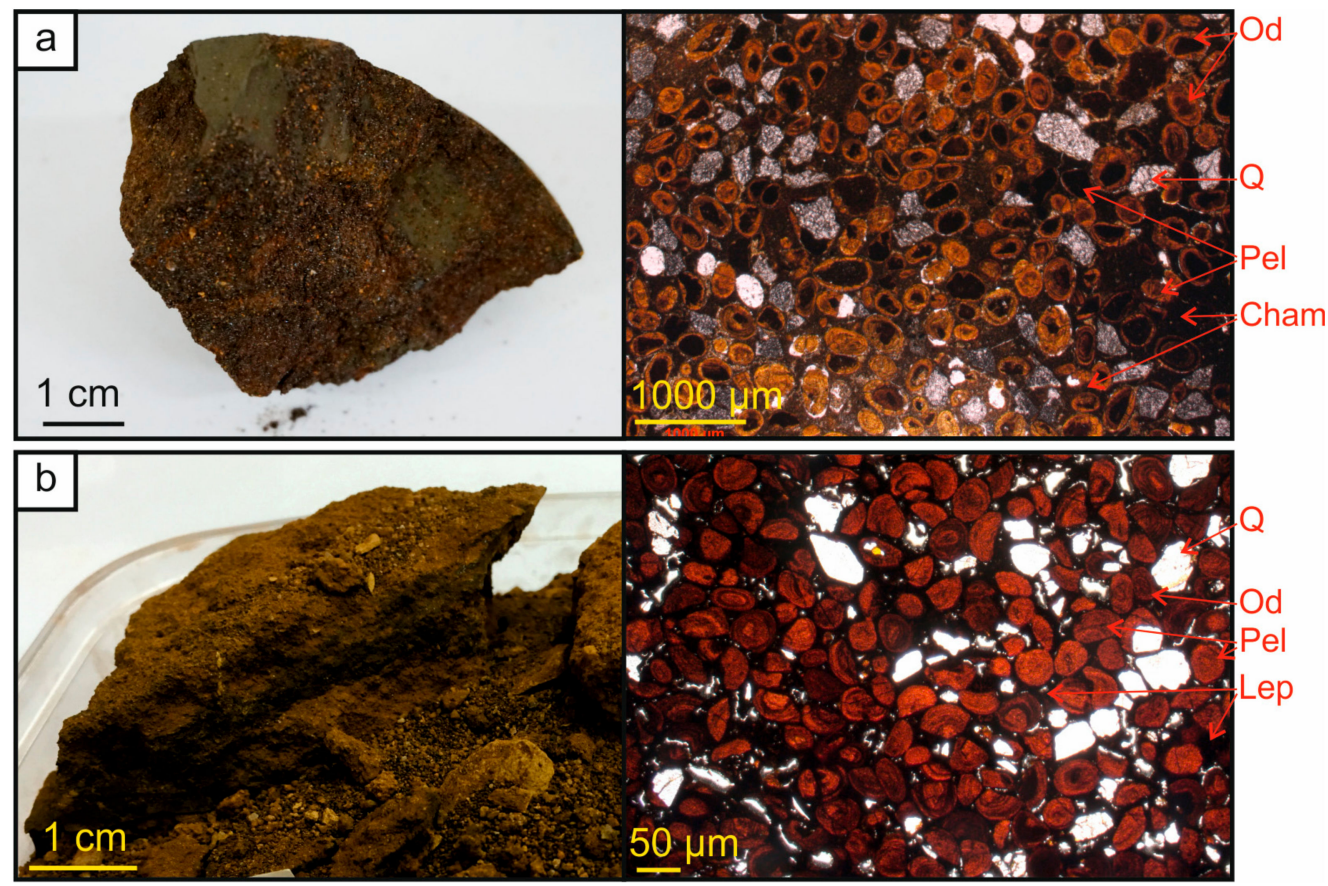

Figure 2. Photos (left) and photomicrographs under transmitted light (right) of the ooidal ironstone (a) of the Bakchar deposit and ooidal ironstone $(\mathbf{b})$ of the Lisakovsk deposit. Od-berthierine-goethite ooids; Pel—goethite-berthierine peloids; Cham—chamosite matrix; Lep—lepidocrocite matrix; Q—quartz.

The total $\mathrm{Fe}_{2} \mathrm{O}_{3}$ content in ironstones varies from 26 to $64.8 \mathrm{wt}$ \% (average value of $45.9 \mathrm{wt}$ \%). The content of $\mathrm{P}_{2} \mathrm{O}_{5}$ in ores varies from 0.3 to $1.7 \mathrm{wt}$ \% (average value of $0.97 \%$ ). The content of $\mathrm{TiO}_{2}, \mathrm{CaO}_{\text {, }}$ and $\mathrm{MnO}$ does not exceed $1 \%$ in all ore varieties. Ooidal ironstones are characterized by relatively low concentrations of $\mathrm{Co}, \mathrm{Ni}$, and $\mathrm{Cu}$ and high concentrations of $\mathrm{Zn}, \mathrm{Pb}, \mathrm{Mo}, \mathrm{V}$, and As in the gross composition of their iron ore, which indicates their hydrothermal source [35]. The total REE content in ore deposits is high and varies from 272.7 to $788.2 \mathrm{ppm}$ [35]. 


\subsubsection{Middle Oligocene Lisakovsk Deposit}

The Lisakovsk deposit (Figure 1c) is located in the central part of the western side of the Turgai trough (Northern Kazakhstan) and belongs to the channel iron deposit. The thickness of the ore deposit reaches $40 \mathrm{~m}$ [29]. The iron resources of the deposit are about 2.8 billion tons [8].

Ooidal ironstones are concentrated in the context of continental Middle Oligocene sediments of the Kutanbulak Formation [61]. Slipchenko [62] classifies them as channel fluvial facies, based on the morphology of their ore bodies, the features of their erosive contacts with underlying rocks, the oblique stratification of the stream type, the presence of large fragments of plant residues (fragments of trunks and lignitized detritus), the sharp vertical and lateral variability of sediments, and the presence of authigenic minerals.

The bed of the ancient river valley of Lisakovka is embedded in the eroded surface of the rocks of the Paleozoic basement. The surface of the Paleozoic basement of the western side of the Turgai trough towards the east plunges slightly and is overlain by Meso-Cenozoic sedimentary rocks. Accordingly, the ancient valley bed of Lisakovka, descending from the Paleozoic basement, passes from the basement to the surface of the sediments in the marine Paleogene, where it cuts the Lower Oligocene-Upper Eocene Chegan clay formation.

As is known [61], the rise of the Ural Mountains system and the Kazakh Highlands, which took place at the end of the Lower Oligocene, caused the regression of the "Chegan" sea basin and its sea's departure from the Turgai trough. Accumulated marine sediments began undergoing erosion. At the same time, a hydrographic network was developing. The rivers flowing down from the Urals easily cut into "Chegan" marine sand and clay sediments, which cover the sides of the Turgai trough. The erosion and the weathering products of the crust, where a significant amount of iron accumulated, were eroded and worn off the sides of the Turgai trough and deposited into the accumulative plains of the Turgai lowland [62]. Thus, the ferruginous zones of the weathering crust developed on various iron-bearing rocks of the ancient basement of the Ural Mountains, and the Kazakh Highlands were the main supplier of iron-rich solutions and/or colloidal suspensions for the formation of ooidal iron ore of the Lisakovsk deposit, according to previous studies [61,62]. According to Yanickiy [61], among the ooidal iron ores in the Lisakovsk deposit, the following texture-mineralogical types are distinguished: Hydrogoethite ooidal ores, which are subdivided into (a) ooidal sands ("poppy ore", "granular"), (b) ooidal ferruginous sandstones (Figure 2b), and (c) pebble-gravel (conglomerate) ore; and hydrogoethite-siderite-chlorite ooidal ores, subdivided into (a) ore sandstone (massive, layered) and (b) ore conglomerate. According to the degree of oxidation, ores are divided into two types: Oxidized ("baked") ores-friable poorly ooidal ores containing an admixture of quartz sand and sometimes fine-grained ochreous matter, as well as harder ooidal iron ore, cemented with iron hydroxides and enriched with tiles and crusts of iron ore.

According to the data of Golubovskaya [29], the composition of ooidal iron ore (Figure 2b) significantly differs based on the ratio between ooids, detrital (mainly quartz and clays), lepidocrocite, or berthierine cement (in wt.\%): $\mathrm{Fe}_{2} \mathrm{O}_{3}$ (total) 43.4-75.0; $\mathrm{SiO}_{2}$ 6.4-37.2, $\mathrm{Al}_{2} \mathrm{O}_{3}$ 0.3-3.6. The content of $\mathrm{P}_{2} \mathrm{O}_{5}$ is less than $1.3 \mathrm{wt} . \%$. Ooidal ores are enriched $\mathrm{Cr}, \mathrm{Ni}, \mathrm{V}$, and $\mathrm{Co}$, as well as $\mathrm{Zn}, \mathrm{Be}$, and As with respect to the average concentration in the Earth's crust [56]. In this study, we collected samples every 0.2 to $0.6 \mathrm{~m}$ on the sides of the quarry from the Central Lisakovsk deposit.

\subsection{Methods}

The mineral forms of REEs in ooidal ironstones (about 125 samples) were studied using scanning electron microscopy (SEM) and transmission electron microscopy (TEM). Polished thin-sections (125 samples) and ooids (fixed to a double-sided 9-mm carbon tape placed on an aluminum stub and carbon coated $(15 \mathrm{~nm})$ ) were scanned under a TESCAN VEGA 3 SBU scanning electron microscope (TESCAN Ltd., Brno, Czech Republic) and OXFORD X-Max 50 energy-dispersive (EDS, OXFORD Instruments, Abingdon, UK) detector with a $20 \mathrm{kV}$ accelerating voltage, specimen current of 5 to $12.2 \mathrm{nA}$, and a spot diameter of approximately $2 \mu \mathrm{m}$. EDS analysis was performed on thin-sections with 
the following parameters: Working distance of $15 \mathrm{~mm}$, specimen current of $12.2 \mathrm{nA}$, and accelerating voltage of $20 \mathrm{kV}$. Apatite was predominantly identified by elemental mapping of polished thin-sections, because its determination by using the backscattered electron detector may lead to a confusion [63] with ferruginous ooids and peloids. The morphology of REE-minerals in ooids and peloids was examined by JEOL JEM-2100F transmission electron microscopy (JEOL Ltd., Tokyo, Japan). A drop of clay suspension was allowed to dry on a copper grid (300 mesh, $3.05 \mathrm{~mm}$ in diameter) coated with carbon film before examining it with TEM operated at $200 \mathrm{kV}$. For samples of interest, Kikuchi band phase identification was performed using a high-resolution field emission SEM TESCAN MIRA3 equipped with an Oxford Instruments electron backscattered diffraction (EBSD, OXFORD Instruments, Abingdon, UK) detector NordlysNano, as well as an energy dispersive (EDS) spectrometer (X-MAX80) for element distribution and true phase identification. High surface quality on a series of previously mechanically polished thin-sections (REEs minerals in ooidal ironstone) for EBSD analysis was achieved using a near parallel Ar+ ion beam technique by a Technoorg Linda SEMPrep2 device. Ion polishing was carried out by applying a beam energy of $6 \mathrm{keV}$ and tilting the surface angle to 5 degree for $30 \mathrm{~min}$. EBSD identification was performed with an electron beam energy of $20 \mathrm{kV}$ and beam current of $10 \mathrm{nA}$.

\section{Results}

Both terrigenous and authigenic REE-bearing minerals were found in both ooidal ironstone deposits. Monazite dominates among terrigenous REE minerals occurring as relatively large grain fragments (from 5 to $120 \mu \mathrm{m}$ ) while xenotime is of secondary importance. Both minerals are relatively abundant in sandstone and ironstone. Nevertheless, this study is mainly focused on authigenic (newly formed) REE minerals. These minerals are mainly hosted by Fe-rich allochems as inclusions and aggregates; they can even form separate concentric zones. Their separate well-formed crystals are very sporadic (Figures 3 and 4). Authigenic LREE-phosphate is predominate and Ce(LREE) oxide is also present.

Authigenic LREE-phosphate was identified in ferruginous ooids (Figure 3a,d,e), peloids (Figure 3c), oncoids (Figure $3 b$ ), or glauconite pellets [64,65]. The assembly of this LREE-phosphate was formed by separate concentric layers in ooids (Figure 3a) or xenomorphic clusters in peloids (Figure 3c) and glauconite globules [65]. The sizes of LREE-phosphate grains vary from 1.8 to $24 \mu \mathrm{m}$. Their forms (outlines) vary between predominantly xenomorphic (Figure 4e), prismatic (Figure 4a), and spherical (Figure $4 \mathrm{~b}$ ) (the latter of which is rare). Very thin $(0.45-2 \mu \mathrm{m})$ concentric lamination (microcortex) was revealed in the cross-sections of the spherules (Figure $4 b$ ).

Other phosphates are apatite (or collophane) and vivianite, which occur only in isolated cases in the Bakchar deposit. Diagenetic apatite is characterized by the peloidal form, whereas detrital apatite exists as grain fragments with sizes up to $500 \mu \mathrm{m}$ in length. Vivianite is rare and occurs as elongated crystals up to $100 \mu \mathrm{m}$ in length.

TEM data reveal that LREE-phosphate occurs as needle-like crystallites up to 100 to $150 \mathrm{~nm}$ in length (Figure 5). Morphologically, phosphate crystals occur as berthierine flakes [59,66]; electron diffraction patterns of the area featuring LREE-phosphate show reflections of 3.6 and $2.6 \AA$ for particles of randomly oriented chlorites, diffuse ring samples from ultrathin goethite, as well as reflections at 2.8, 2.15, and $1.9 \AA$ of a randomly oriented mineral, likely LREE-phosphate (Figure 5). The mineral aggregates between chlorites, goethite, and LREE-phosphates were confirmed by the same crystal morphology and reflection of electron diffraction. Kikuchi lines (Figure 6a) and use of the EBSD detector mainly coincide with the monazite features (Figure 6b). However, these lines cannot uniquely identify LREE-phosphate as monazite. Kikuchi lines of rhabdophane (mineral that are similar in composition) and florencite did not correspond to the Kikuchi lines of the studied LREE-phosphate. 

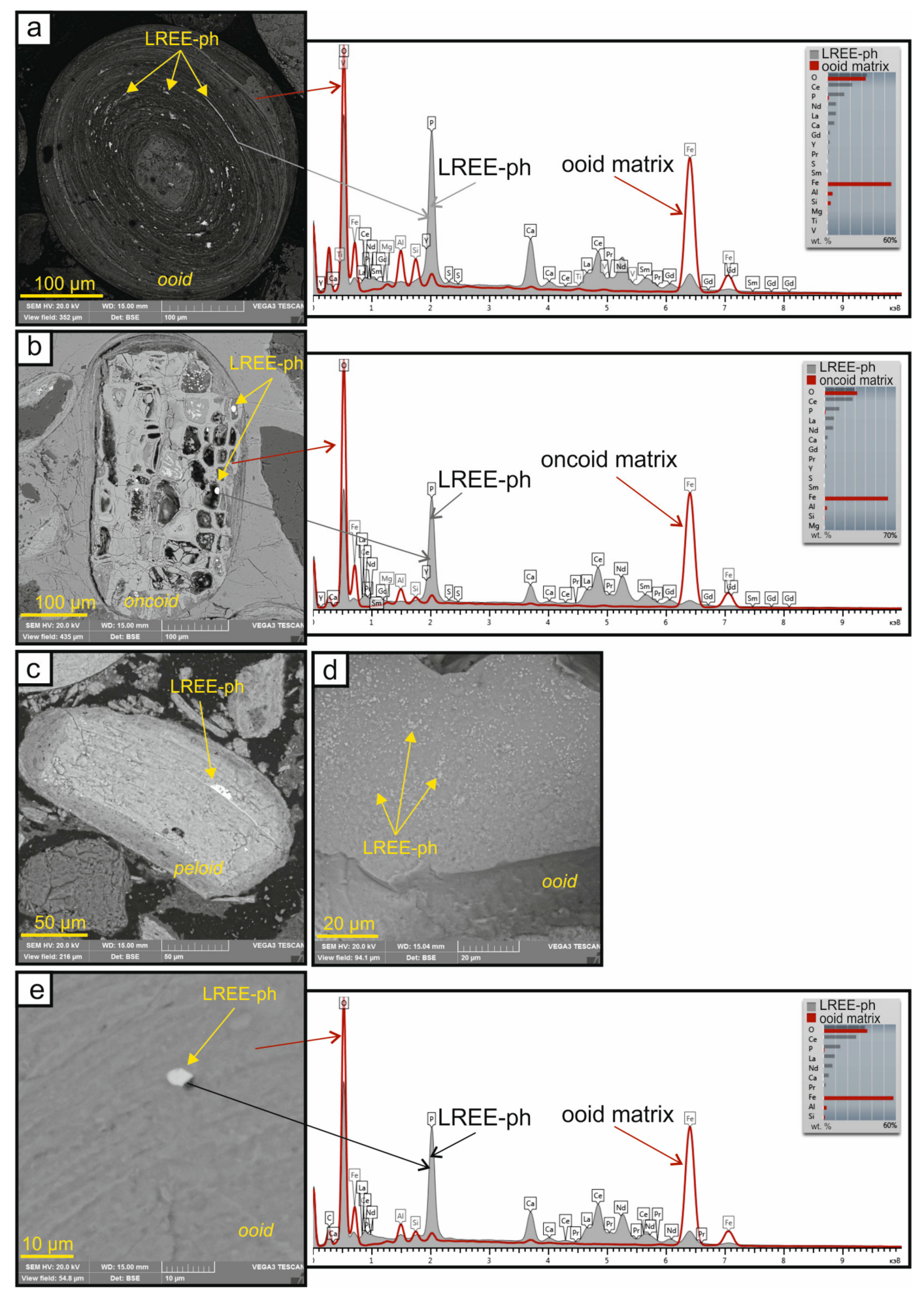

Figure 3. SEM-images with EDS spectra of light rare earth elements (LREEs)-phosphate (LREE-ph) aggregates hosted by ferruginous ooids (a,d,e), oncoids (b), and peloids (c) from the Bakchar (a-d) and Lisakovsk (e) ironstone deposits. (d) LREE-phosphates on the micro-cortex surface of the ooid. The images are backscattered electron (BSE) micro graphs. 

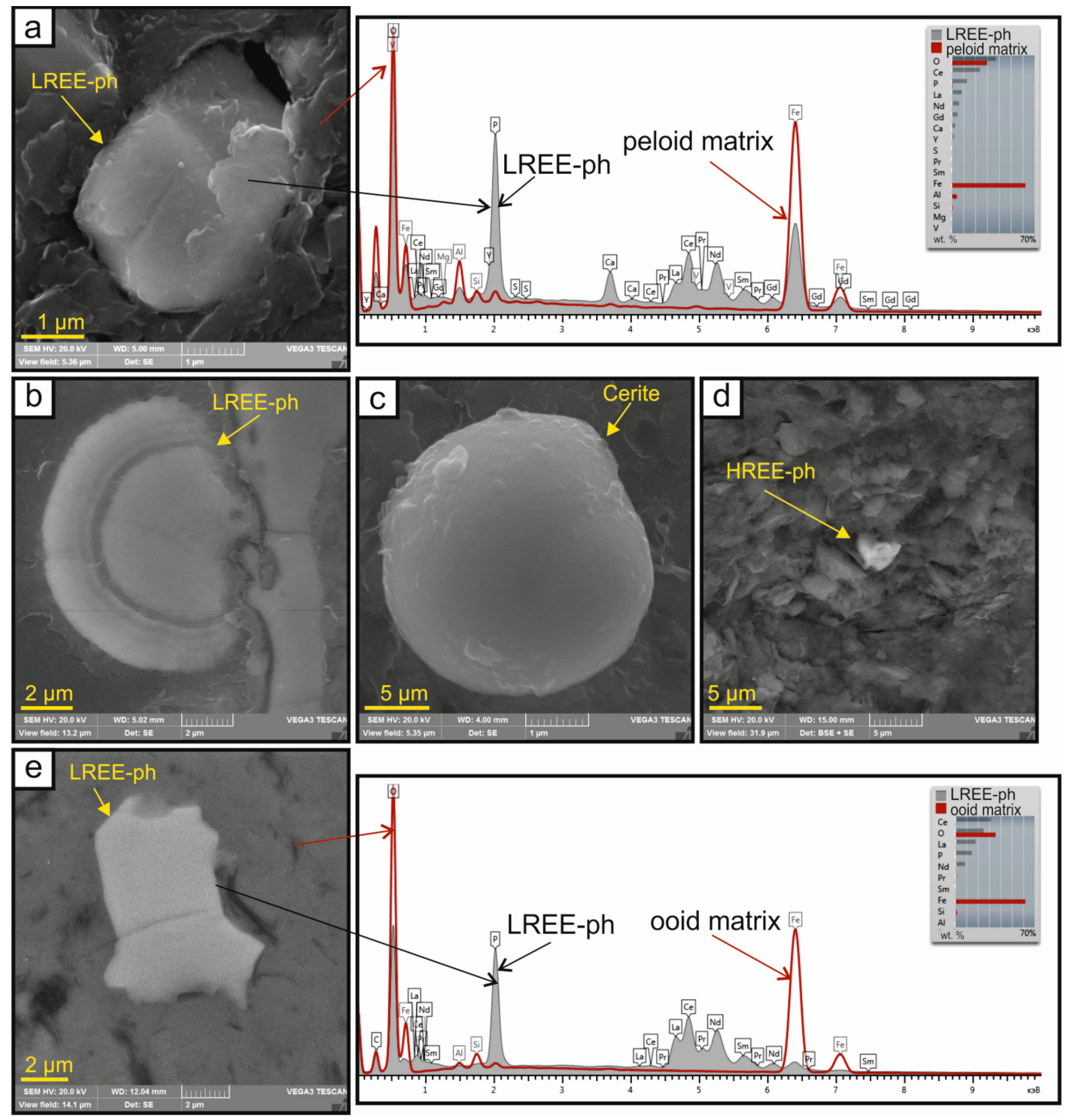

Figure 4. SEM-images with EDS spectra of LREE-phosphates $(\mathbf{a}, \mathbf{b}, \mathbf{e})$, cerite $(\mathbf{c})$, and heavy rare earth elements (HREE)-phosphates (d) crystals and grains buried in the matrix of ferruginous ooids, peloids, and oncoids for Bakchar (a-d) and Lisakovsk (e) ironstone deposits. The images are (a-c,e) secondary electron (SE) and (d) BSE-SE composite micro graphs.

The chemical composition of both detrital and authigenic REE phosphates is shown in Table 1. The average composition of authigenic LREE-phosphate is the follows (in wt.\%): $\mathrm{Ce}_{2} \mathrm{O}_{3}-28.3$, $\mathrm{La}_{2} \mathrm{O}_{3}-12.2, \mathrm{Nd}_{2} \mathrm{O}_{3}-10.3, \mathrm{Pr}_{2} \mathrm{O}_{3}-3.4, \mathrm{Sm}_{2} \mathrm{O}_{3}-2.2, \mathrm{Gd}_{2} \mathrm{O}_{3}-1.4, \mathrm{Y}_{2} \mathrm{O}_{3}-2.5$. Phosphate is a single anion in this mineral $\left(34.2 \mathrm{wt} . \% \mathrm{P}_{2} \mathrm{O}_{5}\right)$. Its characteristic feature is obvious enrichment in $\mathrm{CaO}$ (average content: 6 wt. $\%$ ) in contrast with Th-enrich (up to 7.2 wt. $\% \mathrm{ThO}_{2}$ ) and Ca-poor $(0.5-1.1$ wt.\% CaO) detrital monazite. 


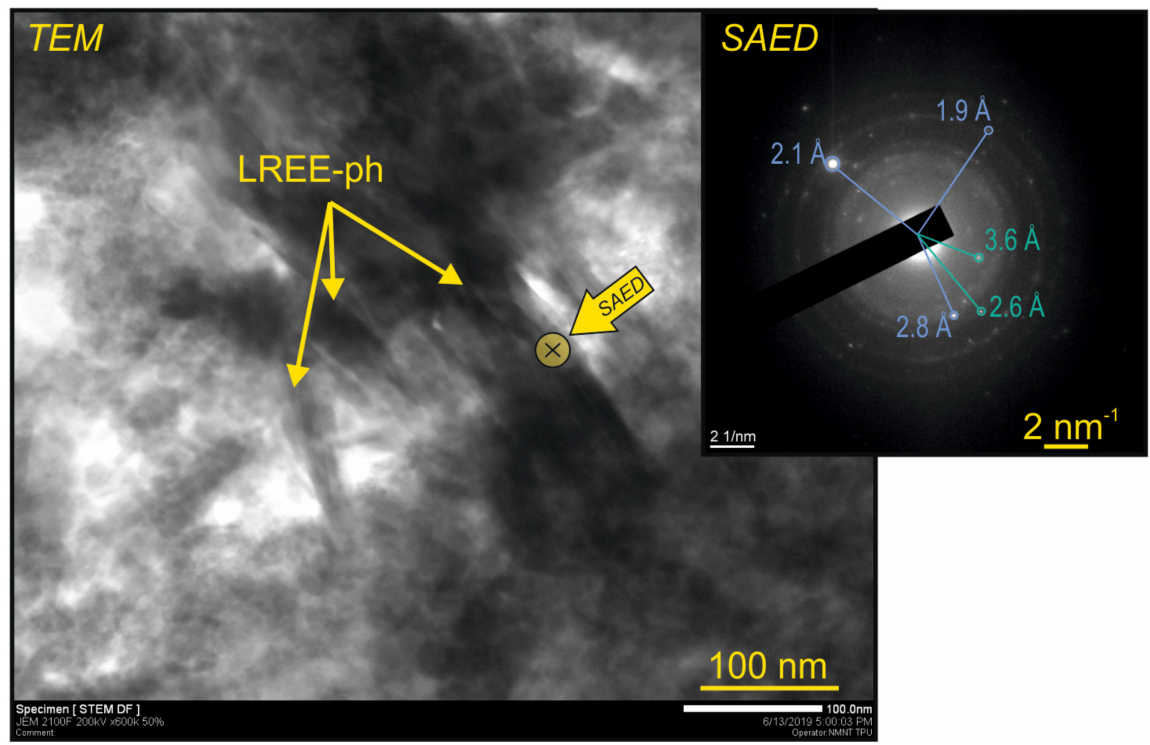

Figure 5. Transmission electron microscope (TEM) images and selected area electron diffraction (SAED) patterns (with main reflections) of LREE-phosphates for the ooidal ironstone of the Bakchar ironstone deposit.

Initial Kikuchi line map

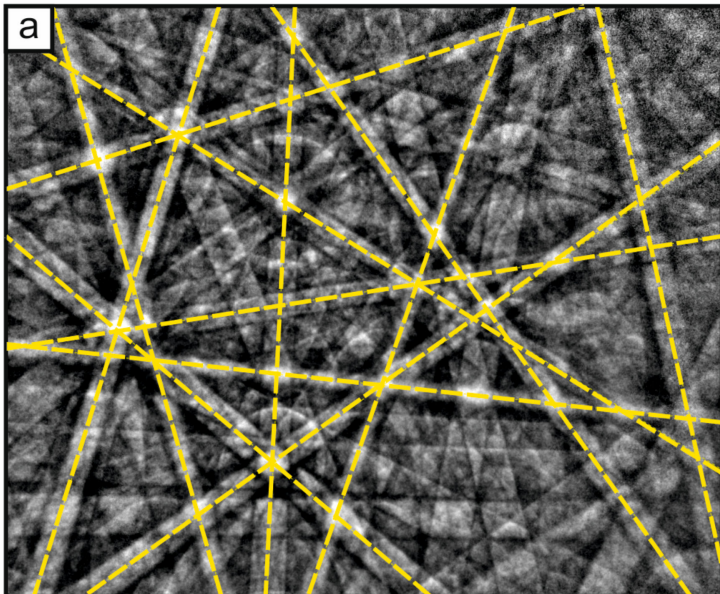

Kikuchi line map with interpretation (comparison with reference monazite)
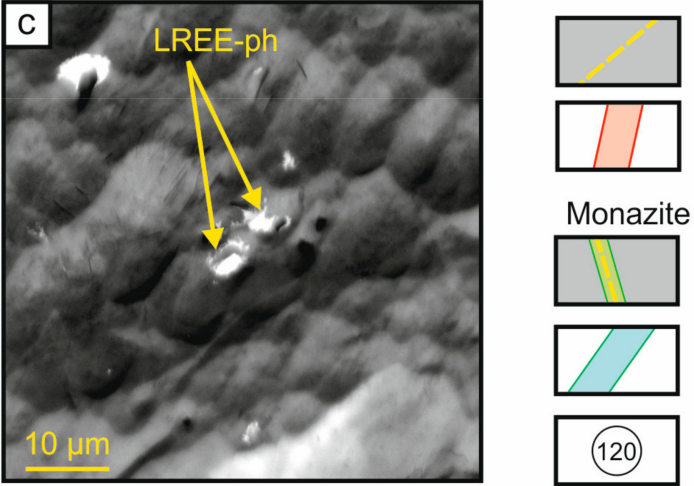

Kikuchi lines of LREE-phosphate

Unknown Kikuchi band

of LREE-phosphate

Monazite Kikuchi bands:

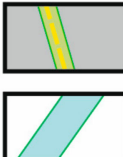

matched with LREE-phosphate

characteristic only for monazite

(do not combined with LREE-phosphate)

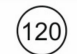

Crystallographic axis of monazite

Figure 6. Kikuchi bands of LREE-phosphate from the ooids of the Bakchar ironstone deposit (a) and its comparison with the reference monazite (b). SEM-image (c) of studied LREE-phosphate (BSE micro graph). 
Table 1. Chemical composition of the LREE-phosphates in ooidal ironstones determined by SEM-EDS.

\begin{tabular}{|c|c|c|c|c|c|c|c|c|c|c|c|c|}
\hline Deposit & $\mathrm{P}_{2} \mathrm{O}_{5}$ & $\mathrm{CaO}$ & $\mathrm{Fe}_{2} \mathrm{O}_{3}$ & $\mathrm{Y}_{2} \mathrm{O}_{3}$ & $\mathrm{La}_{2} \mathrm{O}_{3}$ & $\mathrm{Ce}_{2} \mathrm{O}_{3}$ & $\mathrm{Pr}_{2} \mathrm{O}_{3}$ & $\mathrm{Nd}_{2} \mathrm{O}_{3}$ & $\mathrm{Sm}_{2} \mathrm{O}_{3}$ & $\mathrm{Gd}_{2} \mathrm{O}_{3}$ & $\mathrm{ThO}_{2}$ & Total \\
\hline \multicolumn{13}{|c|}{ Authigenic LREE-phosphate } \\
\hline Bakchar & 28.4 & & 1.1 & & 14.3 & $29.4^{1}$ & 3.1 & 12.5 & 2.6 & 1.5 & & 92.8 \\
\hline Bakchar & 30.9 & 4.3 & 5.0 & & 10.2 & 26.4 & 2.3 & 9.9 & 1.8 & & & 90.7 \\
\hline Bakchar & 30.4 & 4.1 & 3.0 & 2.1 & 9.9 & 28.7 & 2.6 & 9.7 & 2.2 & 1.8 & & 95.1 \\
\hline Bakchar & 47.8 & 8.9 & & & 10.6 & 22.9 & 9.9 & & & & & 100.0 \\
\hline Bakchar & 30.9 & 5.9 & 5.7 & & 9.7 & 24.0 & 2.5 & 9.4 & 1.5 & 1.0 & & 90.6 \\
\hline Bakchar & 29.1 & 1.6 & 2.3 & & 13.3 & 27.3 & 3.3 & 14.4 & 2.9 & & & 94.2 \\
\hline Bakchar & 33.2 & 6.2 & 10.9 & 2.5 & 8.8 & 21.2 & 2.3 & 9.0 & 1.7 & 1.6 & & 97.5 \\
\hline Bakchar & 33.0 & 0.5 & & & 15.6 & 31.9 & 2.8 & 9.7 & & & & 93.5 \\
\hline Bakchar & 25.6 & 0.4 & 1.6 & & 11.7 & 27.7 & 2.9 & 10.9 & 2.3 & 1.1 & & 84.3 \\
\hline Bakchar & 30.0 & 7.5 & 7.6 & 2.5 & 7.6 & 21.2 & 2.6 & 9.0 & 1.7 & 1.2 & & 90.8 \\
\hline Bakchar & 42.0 & & & & 8.8 & 30.5 & 2.7 & 10.6 & & & & 94.5 \\
\hline Bakchar & 29.0 & 0.7 & 1.1 & & 17.7 & 30.9 & 8.5 & & & & & 87.8 \\
\hline Bakchar & 36.9 & 14.4 & & & 8.9 & 28.2 & & 8.2 & & & & 100.0 \\
\hline Bakchar & 42.2 & 9.7 & & & 9.6 & 26.7 & & 8.7 & & & & 100.0 \\
\hline Bakchar & 37.7 & 11.1 & & 2.2 & 10.8 & 26.4 & & 9.5 & & & & 100.0 \\
\hline Bakchar & 41.1 & 11.2 & & & 10.1 & 26.3 & & 8.8 & & & & 100.0 \\
\hline Bakchar & 36.7 & 12.0 & & & 10.2 & 30.9 & & 7.9 & & & & 100.0 \\
\hline Bakchar & 38.3 & 13.4 & & & 9.6 & 26.7 & & 8.6 & & & & 100.0 \\
\hline Bakchar & 41.8 & 12.1 & & & 10.0 & 24.9 & 7.6 & & & & & 96.5 \\
\hline Bakchar & 28.3 & 0.4 & & & 6.3 & 30.4 & 4.2 & 14.0 & 2.4 & 2.3 & & 90.5 \\
\hline Bakchar & 29.6 & 0.6 & 1.6 & & 13.6 & 30.2 & 3.7 & 14.2 & 2.5 & & & 95.9 \\
\hline Bakchar & 35.1 & 0.8 & 1.3 & & 13.4 & 30.9 & 3.1 & 13.0 & & & & 97.7 \\
\hline Bakchar & 26.7 & 4.0 & 1.2 & 1.3 & 15.2 & 18.6 & 3.5 & 13.4 & 2.7 & 1.0 & & 87.4 \\
\hline Bakchar & 30.7 & 5.4 & 1.7 & & 13.1 & 26.9 & 3.5 & 10.8 & & & & 92.1 \\
\hline Bakchar & 31.5 & 5.5 & & 4.2 & 8.4 & 23.6 & 2.3 & 9.7 & & & & 85.2 \\
\hline Lisakovsk & 29.9 & & 4.3 & & 18.7 & 32.5 & 2.7 & 9.9 & 1.9 & & & 100.0 \\
\hline Lisakovsk & 35.9 & 7.0 & & & 13.4 & 33.6 & & 10.2 & & & & 100.0 \\
\hline Lisakovsk & 35.0 & 7.0 & & & 12.0 & 34.0 & 2.6 & 9.5 & & & & 100.0 \\
\hline Lisakovsk & 39.9 & 7.4 & & & 10.8 & 32.7 & & 9.2 & & & & 100.0 \\
\hline Lisakovsk & 39.6 & 7.8 & & & 12.0 & 32.7 & & 8.0 & & & & 100.0 \\
\hline Lisakovsk & 36.3 & 6.8 & & & 14.7 & 35.5 & & 6.7 & & & & 100.0 \\
\hline \multicolumn{13}{|c|}{ Detrital LREE-phosphate (monazite) } \\
\hline Bakchar & 31.1 & 0.5 & 3.6 & & 13.4 & 29.2 & 3.7 & 15.3 & 3.0 & 1.2 & 1.3 & 102.3 \\
\hline Bakchar & 31.5 & 1.1 & & & 14.8 & 30.0 & 2.2 & 10.0 & & & 7.2 & 99.1 \\
\hline Bakchar & 31.6 & & 3.8 & & 11.9 & 26.8 & 2.8 & 13.9 & 1.8 & & & 92.5 \\
\hline Bakchar & 35.2 & & & & 19.4 & 36.3 & 3.5 & 11.9 & & & & 106.3 \\
\hline Bakchar & 28.6 & 0.7 & 0.6 & & 15.5 & 28.7 & 2.9 & 9.5 & 1.5 & 1.0 & 5.6 & 94.7 \\
\hline Bakchar & 38.2 & 0.7 & & & 15.9 & 30.7 & & 13.6 & & & & 100.0 \\
\hline Lisakovsk & 29.1 & 0.7 & 6.5 & & 13.6 & 28.1 & 2.2 & 10.8 & 1.5 & & 5.7 & 98.2 \\
\hline
\end{tabular}

Along with phosphate(s) of $\mathrm{Ce}^{3+}$ and trivalent LREE, another mineral of $\mathrm{Ce}^{4+}$ cerite-(La) was also found in the Bakchar ooidal ironstone deposit (Figure 4c). This mineral occurs as spherical particles $(1.5 \mu \mathrm{m}$ in diameter) and is hosted by an illite matrix with framboidal pyrite. Cerite- $(\mathrm{La})$ is characterized by $44.8 \%$ of $\mathrm{La}_{2} \mathrm{O}_{3}, 36.4 \%$ of $\mathrm{Ce}_{2} \mathrm{O}_{3}, 6.63 \%$ of $\mathrm{FeO}, 3.4 \%$ of $\mathrm{SiO}_{2}$, and $1.3 \%$ of $\mathrm{Al}_{2} \mathrm{O}_{3}$.

Xenotime was found in the iron ore of the Bakchar deposit (Figure 4e) in phyllosilicate or carbonate cement in the form of separated grains with a xenomorphic or scaly form (Figure 4e,f). The grain size varies from 1.8 to $8.5 \mu \mathrm{m}$. The average xenotime composition is represented by $45.0 \mathrm{wt} . \%$ of $\mathrm{Y}_{2} \mathrm{O}_{3}$, 35.5 wt. $\%$ of $\mathrm{P}_{2} \mathrm{O}_{5}, 5.2$ wt. $\%$ of $\mathrm{Dy}_{2} \mathrm{O}_{3}, 3.9$ wt. $\%$ of $\mathrm{Er}_{2} \mathrm{O}_{3}, 3.3$ wt. $\%$ of $\mathrm{Yb}_{2} \mathrm{O}_{3}, 2.7$ wt. $\%$ of $\mathrm{Gd}_{2} \mathrm{O}_{3}$, and 1.8 wt. $\%$ of $\mathrm{Ho}_{2} \mathrm{O}_{3}$.

\section{Discussion}

Authigenic rare-earth elements mineralization is found in the ooidal ironstone of the studied deposits of different ages in the West Siberian Plate. The LREE phosphate (authigenic monazite) is the most common. Similar authigenic phosphates (or "gray" monazite) have been described in other 
sedimentary strata or shales [38,67-70], as well as in ancient analogues of the Phanerozoic ironstone banded iron formation [71]. Because of their microscopic dimensions (up to $24 \mu \mathrm{m}$ ), LREE-phosphates have not been previously detected in many ooidal ironstone formations by optical microscopy methods. However, based on the routine use of SEM, these minerals were found in modern and ancient sediments [72,73].

LREE-phosphates are characterized by diverse shapes and sizes of grains. For LREE-phosphates of the Bakchar deposit, one can trace a morphological series from the smallest xenomorphic particles of LREE-phosphates to their long prismatic crystals. The revealing of concentric microspheres of LREE-phosphates in Bakchar ironstones strongly supports the idea of biogenic REE accumulation during the living cycle of $\left(\mathrm{PO}_{4}\right)^{3-}$-reducing bacteria $[27,74]$. The association of this process with ferruginous spheroids indicates a coupled process of mineral deposition, such as goethite, berthierine (or chamosite), and LREE-phosphate. Since phosphates are confined to the intercortical space between concentric goethite and chamosite laminae (Figure 3a,d,e) and are observed in the form of nano-needle crystallites via TEM (Figure 5), their growth must have occurred after the goethite and chlorite. Weak or absence cationic exchange between ooids and pore water in diagenesis could be due to the relative stability of these forms (spheroids) [75], which ensures the gradual maturation of the phosphates. Their crystallization or aggregation likely occurred inside goethite (with berthierine) spheroids, due to the binding of $\mathrm{LREE}^{3+}$ and sorbing of $\left(\mathrm{PO}_{4}\right)^{3-}$ during precipitation in marine water. Comparing phosphates from ores of the Early Oligocene Lisakovsk and Cretaceous-Paleogene Bakchar deposits, we confirm the higher "maturity" (or crystallinity degree) in the iron ore of the latter. This maturity is likely affected by the degree of consolidation and diagenesis of the ironstone over geological time. We confirm the higher maturity (or crystallinity) of REE-phosphates in the older ironstone deposit. If so, the larger potential for REE accumulation and extraction is possessed by Mesozoic ooidal ironstones relative to younger ones.

The presence of cerite $\left(\mathrm{CeO}_{2}\right)$ in ores of the Bakchar ironstone deposit should also be discussed. This $\mathrm{Ce}^{4+}$ mineral indicates strong oxidizing conditions occurring, for example, in some zones of laterite profiles, where its precipitation causes Ce fractionation from other trivalent REE [76]. Compared to the strictly trivalent $\mathrm{REE}+\mathrm{Y}$, the behavior of $\mathrm{Ce}$ (which is redox sensitive in oxic near-neutral to slightly alkaline Earth surface systems) is markedly different. After the initial surface complexation of $\mathrm{Ce}^{3+}$ on hydrogenetic ferruginous sediments, Ce is partially oxidized at the $\mathrm{Fe}^{3+}$-(oxy)hydroxides' surface [77]. The tetravalent Ce no longer participates in the exchange reactions between the REE + Y(III) solution and surface complexes. Hence, a certain fraction of the scavenged Ce remains as an oxide of $\mathrm{Ce}^{4+}$ (cerite) at the solid's surface. With time, under relatively oxidizing conditions, $\mathrm{Fe}^{3+}$-(oxy)hydroxides preferentially accumulate Ce over the other REE $+\mathrm{Y}$, which eventually results in the positive Ce anomalies $\left(\mathrm{Ce} / \mathrm{Ce}^{*}=[3 \mathrm{Ce} /(2 \mathrm{La}+\mathrm{Nd})]_{\mathrm{SN}}\right.$, where $\mathrm{SN}$ indicates shale-normalized $)$ also observed in hydrogenetic marine Fe-Mn crusts [78]. With high probability, the positive Ce anomaly, which is typical for the PAAS-normalized REE + Y patterns of the ironstone from the Bakchar deposit, is governed by the cerite presence [78]. One can also assume that Ce enrichment of the Bakchar ironstones is a result of the higher maturation degree (or higher diagenetical alteration) of this deposit, which developed under fluctuating redox conditions, which led to Ce immobilization as a solid phase with low solubility.

The sorption of REE and P from seawater on Fe-(oxy)hydroxide particles (colloids) and their coagulation $[38,59,79,80]$ are the main processes by which a close mineral association is produced in the form of ooids, peloids, and oncoids. This mineral association explains the positive correlation between REE and P in ooidal ironstone [18,20,35], given the lack of apatite in the rocks. Based on this, similar REE minerals should be present in almost all deposits of ooidal ironstone.

The composition of LREE phosphate is characterized by a consistent trend: $\mathrm{Ce}>\mathrm{La} \geq \mathrm{Nd}$. The shape of the crystals and fluctuations in their chemical composition (e.g., the absence of Th), as well as the crystal's structure in the form of Kikuchi bands and low-temperature formation conditions do not allow us to identify this mineral as monazite or any other known LREE-phosphate. However, according to its composition and obtained electron diffraction characteristics, it is closest to the so-called 
"nodular" or "gray" monazite $[67,68,73,81]$. Therefore, in the future, we propose to use the name "authigenic monazite" for these phosphates. Today, it can be argued that these minerals are the main REE minerals in ferruginous ooids, peloids, and oncoids. Apatite and vivianite also occurred in the Bakchar deposit [35,47]. However, REE-phosphate should be considered the main mineral form of phosphorus in both Bakchar and Lisakovsk deposits. The search for apatite has been given special attention because of their potential as REE concentrators, such as the example of sedimentary deposits in North Africa [82-84].

The micron sizes and heterogeneous forms of rare-earth phosphates hosted by ferruginous spheroids restrict the mechanical options for their separation. Prospective methods for the enrichment of rare-earth metals from ooidal ironstone include chemical or bacterial leaching [44,46]. It should be stressed that the extraction of REE will be coupled with the removal of phosphorus from the ores, which will positively affect the technological process of beneficiating iron ore. Considering the consistent mineral association of iron minerals and REE phosphates, ooidal ironstone should be considered a complex ore. Thus, the average REE content in the iron ores of the Bakchar deposit is $286.4 \mathrm{ppm}$, and in a separate type of ore, the average REE content is around $500.7 \mathrm{ppm}$ [35]. Given the average REE content in ores (with a total iron content of more than $30 \%$ ), the thickness, area, and density of ore deposits [35], the REE resources within the Bakchar deposit can be estimated at more than 4.5 million tons. At such concentrations, ooidal iron ore should be considered a new natural type of REE ore.

\section{Conclusions}

REE authigenic (LREE-phosphate, cerite) and detrital (monazite, xenotime) minerals occur in ooidal ironstone. The main form of these REE is LREE-phosphate, which is included in ferruginous spheroids and forms a mineral structure with hydroxides (hydrogoethite) and iron phyllosilicates (chamosite and berthierine). The constant presence of the mineral associations in various deposits proves that there is a single mechanism for the deposition of these minerals. Therefore, LREE-phosphate can be present in almost all deposits of ooidal ironstone. The presence of cerite in Bakchar ironstone indicates the immobilization of Ce due to the repeated fluctuations of redox conditions that lead to Ce enrichment in sedimentary deposits.

According to its mineral and chemical characteristics, LREE-phosphate is closest to the so-called authigenic variety of monazite (nodular or "gray" monazite). The micron dimensions of the mineral (up to $24 \mu \mathrm{m}$ ) limit its diagnosis, as well as the mechanical technology for its beneficiation. Given the data on the mineral forms of REE in ooidal ironstones, the latter should be considered complex deposits and a new natural type of REE ore. Thus, this Mesozoic deposit, due to its increased degree of consolidation, offers the greatest potential practical interest.

Author Contributions: A.M. and M.R. conceived and designed the study; M.R., A.R., A.K., O.T. and I.R. performed the laboratory investigations; M.R., A.M., E.A. and E.S. analyzed the data; M.R., E.A. and A.R. contributed materials; M.R. wrote the paper. All authors have read and agreed to the published version of the manuscript.

Funding: This research was funded by the Russian Foundation for Basic Research and Tomsk region (19-45-703002).

Acknowledgments: Laboratory investigations (SEM with EBSD) were carried out within the framework of the Tomsk Polytechnic University Competitiveness Enhancement Program grant (project VIU-OG-61/2019). The contribution of Ella Sokol is done on state assignment of the Institute of Geology and Mineralogy, Siberian Branch, Russian Academy of Sciences. We thank the editor and three anonymous reviewers for their constructive criticisms and revisions, which led to improvement of the manuscript.

Conflicts of Interest: The authors declare no conflict of interest.

\section{References}

1. Petranek, J.; Van Houten, F.B. Phanerozoic Ooidal Ironstones. Czech Geol. Surv. Spec. Pap. 1997, 7, 4-71.

2. Van Houten, F.B.; Bhattacharyya, D.P. Phanerozoic Oolitic Ironstones-Geologic Record and Facies Model. Annu. Rev. Earth Planet. Sci. 1982, 10, 441-457. [CrossRef] 
3. Young, T.P. Phanerozoic ironstones: An introduction and review. Geol. Soc. Lond. Spec. Publ. 1989, 46, ix-xxv. [CrossRef]

4. Sturesson, U. Lower Palaeozoic iron oolites and volcanism from a Baltoscandian perspective. Sediment. Geol. 2003, 159, 241-256. [CrossRef]

5. Heikoop, J.M.; Tsujita, C.J.; Risk, M.J.; Tomascik, T.; Mah, A.J. Modern iron ooids from a shallow-marine volcanic setting: Mahengetang, Indonesia. Geology 1996, 24, 759-762. [CrossRef]

6. Kimberley, M.M. Debate about ironstone: Has solute supply been surficial weathering, hydrothermal convection, or exhalation of deep fluids? Terra Nova 1994, 6, 116-132. [CrossRef]

7. Di Bella, M.; Sabatino, G.; Quartieri, S.; Ferretti, A.; Cavalazzi, B.; Barbieri, R.; Foucher, F.; Messori, F.; Italiano, F. Modern Iron Ooids of Hydrothermal Origin as a Proxy for Ancient Deposits. Sci. Rep. 2019, 9 , 7107. [CrossRef] [PubMed]

8. Ramanaidou, E.R.; Wells, M.A. 13.13—Sedimentary Hosted Iron Ores. In Treatise on Geochemistry; Newnes: London, UK, 2014; pp. 313-355, ISBN 9780080983004.

9. Bekker, A.; Planavsky, N.J.; Krapež, B.; Rasmussen, B.; Hofmann, A.; Slack, J.F.; Rouxel, O.J.; Konhauser, K.O. 9.18-Iron Formations: Their Origins and Implications for Ancient Seawater Chemistry. In Treatise on Geochemistry; Newnes: London, UK, 2014; pp. 561-628, ISBN 9780080983004.

10. Kimberley, M.M. Origin of Oolitic Iron Formations. SEPM J. Sediment. Res. 1979, 49, 111-131.

11. Kimberley, M.M. Exhalative origins of iron formations. Ore Geol. Rev. 1989, 5, 13-145. [CrossRef]

12. Van Houten, F.B.; Hou, H.F. Stratigraphic and palaeogeographic distribution of Palaeozoic oolitic ironstones. Geol. Soc. Mem. 1990, 12, 87-93. [CrossRef]

13. Kholodov, V.N.; Golubovskaya, E.V.; Nedumov, R.I. Origin and prospects of the Cimmerian iron ore basin in Ukraine and Russia. Lithol. Miner. Resour. 2014, 49, 359-380. [CrossRef]

14. Strakhov, N.M. Iron Ore Facies and Their Analogues in the Earth's History: Experience of Historical-Geographical Analysis of Sedimentary Processes. Tr. IGN SSSR. Geol. Ser. 1947, 22, 261-267.

15. Dreesen, R. Oolitic ironstones as event-stratigraphical marker beds within the Upper Devonian of the Ardenno-Rhenish Massif. Geol. Soc. Lond. Spec. Publ. 1989, 46, 65-78. [CrossRef]

16. Mücke, A.; Farshad, F. Whole-rock and mineralogical composition of Phanerozoic ooidal ironstones: Comparison and differentiation of types and subtypes. Ore Geol. Rev. 2005, 26, 227-262. [CrossRef]

17. Mücke, A. Chamosite, siderite and the environmental conditions of their formation in chamosite-type Phanerozoic ooidal ironstones. Ore Geol. Rev. 2006, 28, 235-249. [CrossRef]

18. Garnit, H.; Bouhlel, S. Petrography, mineralogy and geochemistry of the Late Eocene oolitic ironstones of the Jebel Ank, Southern Tunisian Atlas. Ore Geol. Rev. 2017, 84, 134-153. [CrossRef]

19. Afify, A.M.; Sanz-Montero, M.E.; Calvo, J.P. Differentiation of ironstone types by using rare earth elements and yttrium geochemistry-A case study from the Bahariya region, Egypt. Ore Geol. Rev. 2018, 96, 247-261. [CrossRef]

20. Baioumy, H.; Omran, M.; Fabritius, T. Mineralogy, geochemistry and the origin of high-phosphorus oolitic iron ores of Aswan, Egypt. Ore Geol. Rev. 2017, 80, 185-199. [CrossRef]

21. Burkhalter, R.M. Ooidal ironstones and ferruginous microbialites: Origin and relation to sequence stratigraphy (Aalenian and Bajocian, Swiss Jura mountains). Sedimentology 1995, 42, 57-74. [CrossRef]

22. Kholodov, V.N.; Nedumov, R.I.; Golubovskaya, E.V. Facies types of sedimentary iron ore deposits and their geochemical features: Communication 2. Problems of the geochemistry of phanerozoic iron ores. Lithol. Miner. Resour. 2013, 48, 14-47. [CrossRef]

23. Maynard, J.B. Geochemistry of oolitic iron ores, an electron microprobe study. Econ. Geol. 1986, 81, 1473-1483. [CrossRef]

24. Mücke, A. Part II. Postdiagenetic Ferruginization of Phanerozoic (oolitic) Ironstones: A Contribution to Their Geneses. Dev. Sedimentol. 1994, 51, 396-423.

25. Mücke, A. Environmental conditions in the Late Cretaceous African Tethys: Conclusions from a microscopic-microchemical study of ooidal ironstones from Egypt, Sudan and Nigeria. J. Afr. Earth Sci. 2000, 30, 25-46. [CrossRef]

26. Taylor, W.E.G. Sedimentary Rocks | Ironstones. In Encyclopedia of Geology; Academic Press: Cambridge, MA, USA, 2005; pp. 97-107, ISBN 9780123693969. 
27. Salama, W.; El Aref, M.M.; Gaupp, R. Mineral evolution and processes of ferruginous microbialite accretion-An example from the Middle Eocene stromatolitic and ooidal ironstones of the Bahariya Depression, Western Desert, Egypt. Geobiology 2013, 11, 15-28. [CrossRef] [PubMed]

28. Salama, W.; El Aref, M.; Gaupp, R. Mineralogical and geochemical investigations of the Middle Eocene ironstones, El Bahariya Depression, Western Desert, Egypt. Gondwana Res. 2012, 22, 717-736. [CrossRef]

29. Golubovskaya, E.V. Some geochemical features of iron ores from the Lisakov deposit. Lithol. Miner. Resour. 2003, 38, 275-281. [CrossRef]

30. Taylor, K.G.; Konhauser, K.O. Iron in Earth Surface Systems: A Major Player in Chemical and Biological Processes. Elements 2011, 7, 83-88. [CrossRef]

31. Golubovskaya, E.V. Facies and geochemical features of the iron ore complex of the Kerch Peninsula. Lithol. Miner. Resour. 2001, 36, 224-235. [CrossRef]

32. Zitzmann, E.A. The Iron Ore Deposits of Europe and Adjacent Areas = Explan. Notes to the International Map of Iron Ore Deposits in Europe 1:2 500000; Schweizerbart Science Publishers: Stuttgart, Germany, 1978; ISBN 9783510967193.

33. Konhauser, K.O. Diversity of bacterial iron mineralization. Earth-Sci. Rev. 1998, 43, 91-121. [CrossRef]

34. Novoselov, K.A.; Belogub, E.V.; Kotlyarov, V.A.; Filippova, K.A.; Sadykov, S.A. Mineralogical and Geochemical Features of Oolitic Ironstones from the Sinara-Techa Deposit, Kurgan District, Russia. Geol. Ore Depos. 2018, 60, 265-276. [CrossRef]

35. Rudmin, M.; Mazurov, A.; Banerjee, S. Origin of ooidal ironstones in relation to warming events: Cretaceous-Eocene Bakchar deposit, south-east Western Siberia. Mar. Pet. Geol. 2019, 100, 309-325. [CrossRef]

36. Rudmin, M.A.; Mazurov, A.K. Oolitic ores in the Bakchar iron-ore cluster (Tomsk Oblast). Dokl. Earth Sci. 2016, 471, 1238-1241. [CrossRef]

37. Rasmussen, B.; Buick, R.; Taylor, W.R. Removal of oceanic REE by authigenic precipitation of phosphatic minerals. Earth Planet. Sci. Lett. 1998, 164, 135-149. [CrossRef]

38. Rasmussen, B. Early-diagenetic REE-phosphate minerals (florencite, gorceixite, crandallite, and xenotime) in marine sandstones: A major sink for oceanic phosphorus. Am. J. Sci. 1996, 296, 601-632. [CrossRef]

39. Rasmussen, B. Radiometric dating of sedimentary rocks: The application of diagenetic xenotime geochronology. Earth-Sci. Rev. 2005, 68, 197-243. [CrossRef]

40. Marino, E.; González, F.J.; Kuhn, T.; Madureira, P.; Wegorzewski, A.V.; Mirao, J.; Medialdea, T.; Oeser, M.; Miguel, C.; Reyes, J.; et al. Hydrogenetic, Diagenetic and Hydrothermal Processes Forming Ferromanganese Crusts in the Canary Island Seamounts and Their Influence in the Metal Recovery Rate with Hydrometallurgical Methods. Minerals 2019, 9, 439. [CrossRef]

41. Gamaletsos, P.N.; Godelitsas, A.; Filippidis, A.; Pontikes, Y. The Rare Earth Elements Potential of Greek Bauxite Active Mines in the Light of a Sustainable REE Demand. J. Sustain. Metall. 2019, 5, 20-47. [CrossRef]

42. Hartmann, B.T.; Gaupp, R.; Oberhaensli, R. Authigenic rare earth fluorocarbonates (synchiste) in Rotliegend sandstone from the North-German Basin: Constraints for REE mobility during diagenesis. Gaea Heidelb. 1997, 3, 158.

43. Krishnamurthy, N.; Gupta, C.K.; Gupta, C.K. Extractive Metallurgy of Rare Earths; CRC Press: Boca Raton, FL, USA, 2015; ISBN 9780429100987.

44. Dutrizac, J.E.; Soriano, C. Behaviour of the rare earths during goethite $(\alpha-\mathrm{FeOOH})$ precipitation from sulphate-based solutions. Hydrometallurgy 2018, 176, 87-96. [CrossRef]

45. Baioumy, H.M. Iron-phosphorus relationship in the iron and phosphorite ores of Egypt. Chem. Erde Geochem. 2007, 67, 229-239. [CrossRef]

46. Wang, J.; Shen, S.; Kang, J.; Li, H.; Guo, Z. Effect of ore solid concentration on the bioleaching of phosphorus from high-phosphorus iron ores using indigenous sulfur-oxidizing bacteria from municipal wastewater. Process Biochem. 2010, 45, 1624-1631. [CrossRef]

47. Belous, N.C.; Nikolaeva, I.V.; Kazansky, Y.P.; Berdnikov, A.P.; Klyarovskiy, V.M.; Kuznetsov, V.P.; Babin, A.A. The Western-Siberian Iron Ore Basin; Siberian Branch of the Academy of Sciences of the USSR: Novosibirsk, Russia, 1964.

48. Podobina, V.M.; Kseneva, T.G. Upper Cretaceous zonal stratigraphy of the West Siberian Plain based on foraminifera. Cretac. Res. 2005, 26, 133-143. [CrossRef] 
49. Podobina, V.M. Substantiation of the Paleocene-Eocene boundary in western Siberia by foraminifers. Stratigr. Geol. Correl. 1998, 6, 142-149.

50. Lebedeva, N.K.; Kuzmina, O.B.; Sobolev, E.S.; Khazina, I.V. Stratigraphy of Upper Cretaceous and Cenozoic deposits of the Bakchar iron ore deposit (southwestern Siberia): New data. Stratigr. Geol. Correl. 2017, 25, 76-98. [CrossRef]

51. Lebedeva, N.K.; Aleksandrova, G.N.; Shurygin, B.N.; Ovechkina, M.N.; Gnibidenko, Z.N. Paleontological and magnetostratigraphic data on Upper Cretaceous deposits from borehole no. 8 (Russkaya Polyana District, Southwestern Siberia). Stratigr. Geol. Correl. 2013, 21, 48-78. [CrossRef]

52. Gnibidenko, Z.N.; Lebedeva, N.K.; Levicheva, A.V. Magnetostratigraphy of the Campanian-Maastrichtian Bakchar Basin (southeastern West Siberia). Russ. Geol. Geophys. 2015, 56, 1652-1661. [CrossRef]

53. Nikolaeva, I.V. Bakchar Oolitic Iron Ore Deposit; Siberian Branch of the Academy of Sciences of the USSR: Novosibirsk, Russia, 1967.

54. Kontorovich, A.E.; Ershov, S.V.; Kazanenkov, V.A.; Karogodin, Y.N.; Kontorovich, V.A.; Lebedeva, N.K.; Nikitenko, B.L.; Popova, N.I.; Shurygin, B.N. Cretaceous paleogeography of the West Siberian sedimentary basin. Russ. Geol. Geophys. 2014, 55, 582-609. [CrossRef]

55. Smith, A.G.; Smith, D.G.; Funnell, B.M. Atlas of Mesozoic and Cenozoic Coastlines; Cambridge University Press: Cambridge, UK, 1994; ISBN 0521451558.

56. Hooker, J.J.; Dashzeveg, D. Evidence for Direct Mammalian Faunal Interchange between Europe and Asia near the Paleocene-Eocene Boundary; Geoscience World: McLean, VA, USA, 2003; Volume 369.

57. Iakovleva, A.I.; Brinkhuis, H.; Cavagnetto, C. Late Palaeocene-Early Eocene dinoflagellate cysts from the Turgay Strait, Kazakhstan; correlations across ancient seaways. Palaeogeogr. Palaeoclimatol. Palaeoecol. 2001, 172, 243-268. [CrossRef]

58. Vibe, Y.; Bunge, H.P.; Clark, S.R. Anomalous subsidence history of the West Siberian Basin as an indicator for episodes of mantle induced dynamic topography. Gondwana Res. 2018, 53, 99-109. [CrossRef]

59. Gehring, A.U. The formation of goethitic ooids in condensed Jurassic deposits in northern Switzerland. Geol. Soc. Spec. Publ. 1989, 46, 133-139. [CrossRef]

60. Rudmin, M.; Roberts, A.P.; Horng, C.S.; Mazurov, A.; Savinova, O.; Ruban, A.; Kashapov, R.; Veklich, M. Ferrimagnetic Iron Sulfide Formation and Methane Venting Across the Paleocene-Eocene Thermal Maximum in Shallow Marine Sediments, Ancient West Siberian Sea. Geochem. Geophys. Geosyst. 2018, 19, 1-22. [CrossRef]

61. Yanickiy, A.L. Oligocene Oolitic Iron Ores of Northern Turgai and Its Genesis; AN USSR: Moscow, Russia, 1960. (In Russia)

62. Slipchenko, B.V. About two genetic types of oolitic iron ores of the Lisakovsk deposit (Northern Kazakhstan). Russ. Geol. J. 1981, 41, 53-61. (In Russia)

63. Baele, J.-M.; Dreesen, R.; Dusar, M. Assessing apatite cathodoluminescence as a tool for sourcing oolitic ironstones. Anthropol. Praehist. 2015, 126, 57-67.

64. Rudmin, M.A.; Mazurov, A.K.; Reva, I.V. Mineral microinclusions in glauconite of bakchar deposit (tomsk region). Bull. Tomsk Polytech. Univ. Geo. Assets Eng. 2016, 327, 54-64.

65. Rudmin, M.; Banerjee, S.; Mazurov, A. Compositional variation of glauconites in Upper Cretaceous-Paleogene sedimentary iron-ore deposits in South-eastern Western Siberia. Sediment. Geol. 2017, 355, 20-30. [CrossRef]

66. Hughes, C.R. The application of analytical transmission electron microscopy to the study of oolitic ironstones: A preliminary study. Geol. Soc. Lond. Spec. Publ. 1989, 46, 121-131. [CrossRef]

67. Burnotte, E.; Pirard, E.; Michel, G. Genesis of gray monazites: Evidence from the Paleozoic of Belgium. Econ. Geol. 1989, 84, 1417-1429. [CrossRef]

68. Alipour-Asll, M.; Mirnejad, H.; Milodowski, A.E. Occurrence and paragenesis of diagenetic monazite in the upper Triassic black shales of the Marvast region, South Yazd, Iran. Mineral. Petrol. 2012, 104, 197-210. [CrossRef]

69. Halpin, J.A.; Jensen, T.; McGoldrick, P.; Meffre, S.; Berry, R.F.; Everard, J.L.; Calver, C.R.; Thompson, J.; Goemann, K.; Whittaker, J.M. Authigenic monazite and detrital zircon dating from the Proterozoic Rocky Cape Group, Tasmania: Links to the Belt-Purcell Supergroup, North America. Precambrian Res. 2014, 250, 50-67. [CrossRef] 
70. Auer, G.; Reuter, M.; Hauzenberger, C.A.; Piller, W.E. The impact of transport processes on rare earth element patterns in marine authigenic and biogenic phosphates. Geochim. Cosmochim. Acta 2017, 203, 140-156. [CrossRef]

71. Alibert, C. Rare earth elements in Hamersley BIF minerals. Geochim. Cosmochim. Acta 2016, 184, 311-328. [CrossRef]

72. Bern, C.R.; Shah, A.K.; Benzel, W.M.; Lowers, H.A. The distribution and composition of REE-bearing minerals in placers of the Atlantic and Gulf coastal plains, USA. J. Geochem. Explor. 2016, 162, 50-61. [CrossRef]

73. Lazareva, E.V.; Zhmodik, S.M.; Prokopiev, A.V.; Karmanov, N.S.; Sergeenko, A.I. Nodular monazite from placers in the Kular Ridge (Arctic Siberia, Russia): Composition and age. Russ. Geol. Geophys. 2018, 59, 1330-1347. [CrossRef]

74. Barale, L.; D'atri, A.; Martire, L. The Role of Microbial Activity In the Generation of Lower Cretaceous Mixed FE-Oxide-phosphate Ooids from the Provencal Domain, French Maritime Alps. J. Sediment. Res. 2013, 83, 196-206. [CrossRef]

75. Berner, R.A. Goethite stability and the origin of red beds. Geochim. Cosmochim. Acta 1969, 33, $267-273$. [CrossRef]

76. Berger, A.; Janots, E.; Gnos, E.; Frei, R.; Bernier, F. Rare earth element mineralogy and geochemistry in a laterite profile from Madagascar. Appl. Geochem. 2014, 41, 218-228. [CrossRef]

77. Bau, M.; Schmidt, K.; Koschinsky, A.; Hein, J.; Kuhn, T.; Usui, A. Discriminating between different genetic types of marine ferro-manganese crusts and nodules based on rare earth elements and yttrium. Chem. Geol. 2014, 381, 1-9. [CrossRef]

78. Bau, M.; Koschinsky, A. Oxidative scavenging of cerium on hydrous Fe oxide: Evidence from the distribution of rare earth elements and yttrium between Fe oxides and Mn oxides in hydrogenetic ferromanganese crusts. Geochem. J. 2009, 43, 37-47. [CrossRef]

79. Pufahl, P.K.; Hiatt, E.E. Oxygenation of the Earth's atmosphere-ocean system: A review of physical and chemical sedimentologic responses. Mar. Pet. Geol. 2012, 32, 1-20. [CrossRef]

80. Sturesson, U. Llanvirnian (Ord.) iron ooids in Baltoscandia: Element mobility, REE distribution patterns, and origin of the REE. Chem. Geol. 1995, 125, 45-60. [CrossRef]

81. Kryza, R.; Zalasiewicz, J.A.; Charnley, N.; Milodowski, A.E.; Kostylew, J.; Tyszka, R. In situ growth of monazite in anchizonal to epizonal mudrocks: First record from the Variscan accretionary prism of the Kaczawa Mountains, West Sudetes, SW Poland. Geol. Sudet. 2004, 36, 39-51.

82. El-Habaak, G.; Askalany, M.; Abdel-Hakeem, M. Possibility of Mixed Origin of Rare Earth Elements in Sedimentary Marine Apatites: A Case Study from Phosphorites in the Cretaceous (Campanian-Maastrichtian) Duwi Formation, Abu-Tartur Plateau, Egypt. J. Geol. 2019, 127, 643-663. [CrossRef]

83. Baioumy, H. Rare earth elements and sulfur and strontium isotopes of upper Cretaceous phosphorites in Egypt. Cretac. Res. 2011, 32, 368-377. [CrossRef]

84. Kechiched, R.; Laouar, R.; Bruguier, O.; Laouar-Salmi, S.; Ameur-Zaimeche, O.; Foufou, A. Preliminary Data of REE in Algerian Phosphorites: A Comparative Study and Paleo-redox Insights. Procedia Eng. 2016, 138, 19-29. [CrossRef]

(C) 2019 by the authors. Licensee MDPI, Basel, Switzerland. This article is an open access article distributed under the terms and conditions of the Creative Commons Attribution (CC BY) license (http://creativecommons.org/licenses/by/4.0/). 